\title{
Construction Sector in the Czech Republic and Poland: Focus on the Housing Segment in Selected Regions
}

\author{
Monika Płaziak, Anna Irena Szymańska
}

\begin{abstract}
A B S T R A C T
Objective: The paper presents a comparative analysis of the construction sector in the Czech Republic and Poland, with a particular focus on the housing segment in selected regions. The authors compared the size and growth of the housing segment.

Research Design \& Methods: To achieve the purpose, spatial and dynamic analyses of the construction sector indicators were conducted, with a particular emphasis on the housing segment (i.e. growth of construction sector production, completed dwellings per 1000 inhabitants).
\end{abstract}

Findings: In global economic crisis, the construction production fluctuation displayed a similar trend for both countries, with the worst indicators reported in 2010 and 2011. The main analysis focused on the dwelling segment. The Czech Republic reported a negative growth $(-2.4 \%)$ in the number of completed dwellings in the period, while Poland reported a positive growth of $32.6 \%$.

Implications \& Recommendations: Analysed countries differ regarding the construction industry output, which depends on the different population potential and uneven distribution of construction projects, particularly in the housing segment. Nonetheless, a common tendency was observed in the housing segment showing an intensified growth in the output in the areas that had seen fewer investment projects.

Contribution \& Value Added: Comparison of the construction sector status and development in selected regions of the Czech Republic and Poland can be helpful to entrepreneurs, investors and employees from both countries in recognizing a potential demand for dwellings.

\begin{tabular}{ll}
\hline Article type: & research paper \\
Keywords: & construction sector; housing segment; Czech Republic; Poland \\
JEL codes: & R1, R3
\end{tabular}

Received: 15 March 2014

Revised: 17 April 2014

Accepted: 15 May 2014

\section{Suggested citation:}

Płaziak, M., \& Szymańska, A.I. (2014). Construction Sector in the Czech Republic and Poland: Focus on the Housing Segment in Selected Regions. Entrepreneurial Business and Economics Review, 2(2), 47-63. 


\section{INTRODUCTION}

Transformations occurring in the today's world economy, related to the transition from the industrial towards the information-based phase in the development of civilisation, are also reflected in the economic development of small-scale spatial patterns, namely regional or even local patterns (Rachwał, 2011, p. 1; Zioło, 2008, pp. 11-22; Zioło, 2001, pp. 9-20; Borowiec \& Dorocki, 2011, pp. 215-216). The evolving business environment creates a growing disparity in the development of specific areas within a country. One of the reasons is evolving employment structure in economic sectors or the growth of entrepreneurial activity of people who are a labour resource, as well as changing location factors which apply to enterprises (Płaziak \& Szymańska, 2014, p. 374; Szymańska \& Płaziak, 2014, p. 381). The construction industry is one of the sectors considerably affecting the development of Polish and Czech economy (Information on the Polish construction industry for the years 2012-2013, p.10).

\section{MATERIAL AND METHODS}

The key purpose of the paper is to define a growth of the construction sector in the Czech Republic and Poland and in some regions of both countries in the period between 2006 and 2012 - shortly before and during the world crisis. Therefore, spatial and dynamic analyses of the construction sector indicators were conducted, with a particular focus on the housing segment. The increase in the number of dwellings is accompanied by today's suburbanisation processes, related to metropolisation, visible increasingly in central Europe. The demand for new dwellings is related to the socio-economic development and growing human needs, which make it an important metric of the level and quality of life (Płaziak, 2004a, pp. 108-110; Płaziak, 2004b, pp. 121-122; Zborowski, 2005, p. 241; Zuzańska-Żyśko, 2014, p. 375).

The analysis is based on official statistics (The Czech Statistical Office, The Central Statistical Office of Poland), brokerage reports (Dom Maklerski BDM S.A., Budownictwo) and real estate market reports (KPB, 2012), which were used to describe the general state of construction sector in the Czech Republic as well as Poland in the time of the global economic crisis. The paper identifies the broad trends of change in the sector and what is more, the detailed analysis of dwelling segment is presented and discussed.

The paper compares the size and growth of dwelling segment in the Czech Republic and in Poland, focusing on selected regions: Moravia Silesia, Olomouc, South Moravia, Zlín in the eastern part of the Czech Republic and the Małopolska Region in Poland. To realize the purpose, we applied the indicator of completed dwellings per 1000 inhabitants and its dynamics and regional diversity (on the basis of the Czech Statistical Office and the Central Statistical Office). The analysis covers the period between 2006 and 2012 - the time shortly before the world economic crisis and during the crisis. 


\section{RESULTS AND DISCUSSION}

\section{The Condition of the Czech Construction Sector}

The analysis of the GDP growth in the Czech economy in the period from 2006 to 2010 shows a considerable diversification of economic development. Although the rate of the GDP growth in 2008 year-on-year (3.1\%) was lower than the change between 2007 and 2006 (5.7\%), the indicator confirmed the economic growth in the Czech Republic. Unfortunately, in the late 2008, the country's economy began deteriorating rapidly. At the time, the global crisis could be clearly noticed in Central and Eastern Europe. In 2008, the Czech economy continued growing; however, the GDP growth (3.1\% YOY) was not as high as in 2007 (5.7\% YOY). In 2009 (the peak of the crisis), the GDP growth dropped by nearly 5 percentage points. Two consecutive years (2010 and 2011) saw a slight recovering trend (a positive GDP); however, the reported GDP growth remained significantly lower than in 2007-2008 (KPB, 2012, p. 22).

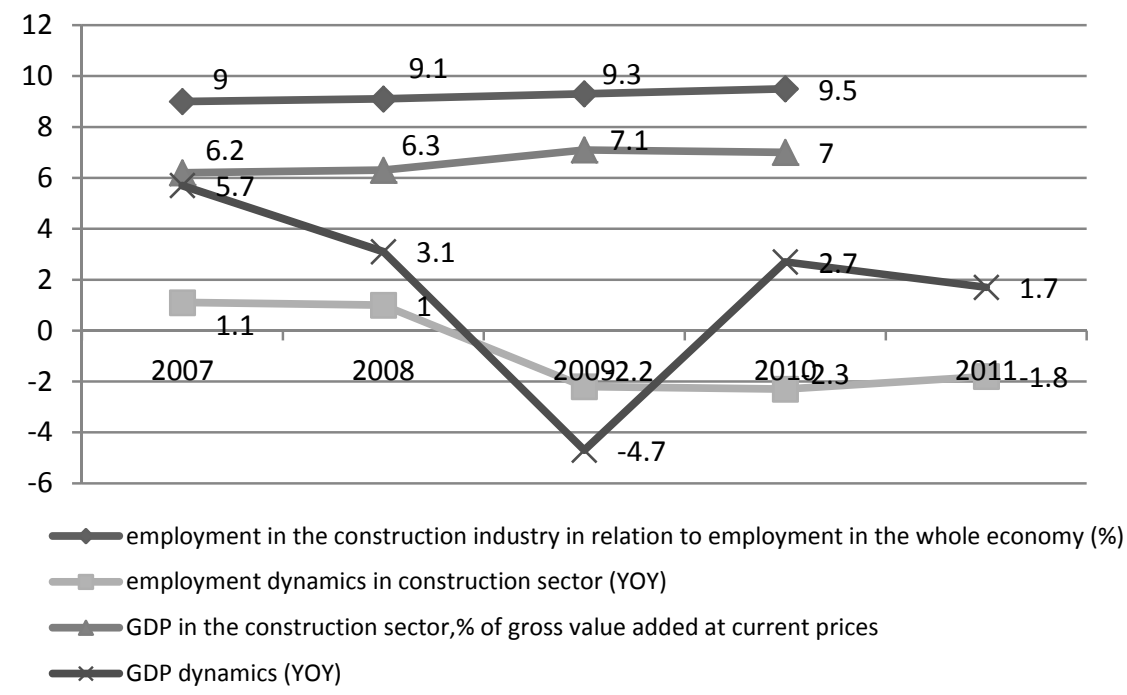

Figure 1. Indicators describing the condition of the Czech construction sector

Source: based on KPB (2012, p. 21); ASM - Centrum Badań i Analiz Rynku, after: EUROSTAT, UNECE data.

The employment in the construction sector is relatively high when compared to the entire Czech economy. Employment in the construction sector accounts for $9 \%$ of the Czech labour market. The analysis of the employment volume 2007-2010 shows a continuous growth (from $9 \%$ in 2007 to $9.5 \%$ in 2010). The data show that the 2008 crisis did not have any impact on the ratio. However, an analysis of the employment growth in the construction sector shows something entirely different. Starting from 2009, the number of persons employed in the construction industry was dropping by approx. $2 \%$ (YOY) each year, which may be the outcome of the 2008 crisis. Given the growing percentage of people employed in the sector, which is contradictory to the abovementioned trend, one may conclude that the downward trend in employment was more 
visible in other sectors of the economy. On the other hand, the GDP in the construction sector in the period 2009-2010 was, on average, higher by approx. $1 \%$ than the same in the period 2007-2008 (Figure 1).

An analysis of the Czech housing segment in 2007-2011 shows a downward trend, confirmed by such indicators as the number of building permits issued for dwellings, the number of completed dwellings and the number of dwellings under construction in the analysed years. On a positive note, the number of building permits for dwellings mildly increased in 2011, which may be then reflected in the larger number of new dwellings under construction and of completed dwellings ${ }^{1}$ in the coming years (Table 1 ).

Table 1. Indicators illustrating the Czech housing construction market, 2007-2011

\begin{tabular}{|l|r|r|r|}
\hline \multicolumn{1}{|c|}{ Year } & \multicolumn{1}{|c|}{$\begin{array}{c}\text { Building permits } \\
\text { (for dwellings) }\end{array}$} & Completed dwellings & \multicolumn{1}{c|}{$\begin{array}{c}\text { Dwellings under } \\
\text { construction }\end{array}$} \\
\hline 2007 & - & 41.6 & 43.8 \\
\hline 2008 & 122.2 & 38.4 & 43.5 \\
\hline 2009 & 112.7 & 38.5 & 37.3 \\
\hline 2010 & 105.7 & 36.4 & 28.1 \\
\hline 2011 & 107.2 & 28.6 & 27.5 \\
\hline
\end{tabular}

Source: based on KPB (2012, p. 23); ASM - Centrum Badań i Analiz Rynku, after: the Czech Statistical Office.

Considerable regional differences in demand are observed in the Czech Republic. The highest demand is reported in the central part of the Czech Republic, Moravia-Silesia (Ostrava), Olomouc, Southern Moravia, and in the western part of the country.

The Czech construction market is highly competitive due to, inter alia, very few or hardly any new investment projects coupled with a dropping demand. The demand for construction services as well as project budgets are shrinking. It is likely that the fierce competition on the market is a consequence of its small size (a small target group).

\section{Construction Sector in Poland}

The construction industry is an important sector of the Polish economy. The data of the Central Statistical Office (GUS) reported a growth of $6.4 \%$ in 2010 and a growth approaching 12\% in 2011 (Figure 2). The Polish construction market reached its peak in 2011, which came as a direct consequence of implementing infrastructural investment projects financed under the OP I\&E (Operational Programme Infrastructure and Environment 2007-2013, approved by the European Commission on 7th December 2007) and of the organisation of EuroCup 2012.

The analysis of the value of construction output in Poland, 1993-2011, confirms that the Polish construction sector did not experience any recession since the period 2000-2003. The construction output has been continuously growing since 2004 (Figure 3 ). Since 2005, the share of public contracts in the construction sector in the total number and value of public contracts were growing steadily (Kozik \& Starzyk, 2011).

\footnotetext{
${ }^{1}$ In 2010, an average (typical) flat in multi-family residential buildings was comprised of two rooms and a kitchen, with the total floor area of $55 \mathrm{~m}^{2}$. The average price of such a flat was 2.6 million CZK (approx. EUR 106 thousand). Residential premises in single-family buildings were much larger - their average floor area equalled $95 \mathrm{~m}^{2}$, and they were comprised of five rooms and a kitchen. The average price in this case was CZK $3.2 \mathrm{M}$ (approx. EUR 130 thousand) (Source: http://praha.trade.gov.pl/pl).
} 


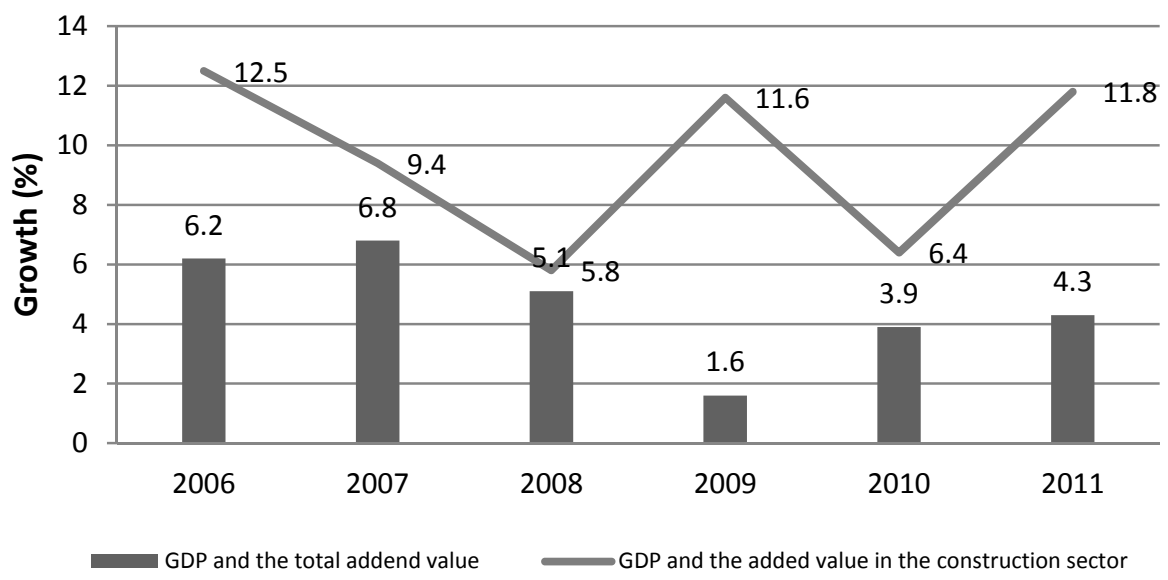

Figure 2. Annual GDP and gross added value growth rate in Polish industry and construction sector in the years 2006-2011

Source: based on GUS data; Informacja o sytuacji społeczno-gospodarczej kraju rok 2011, 2012; BAA (2011).

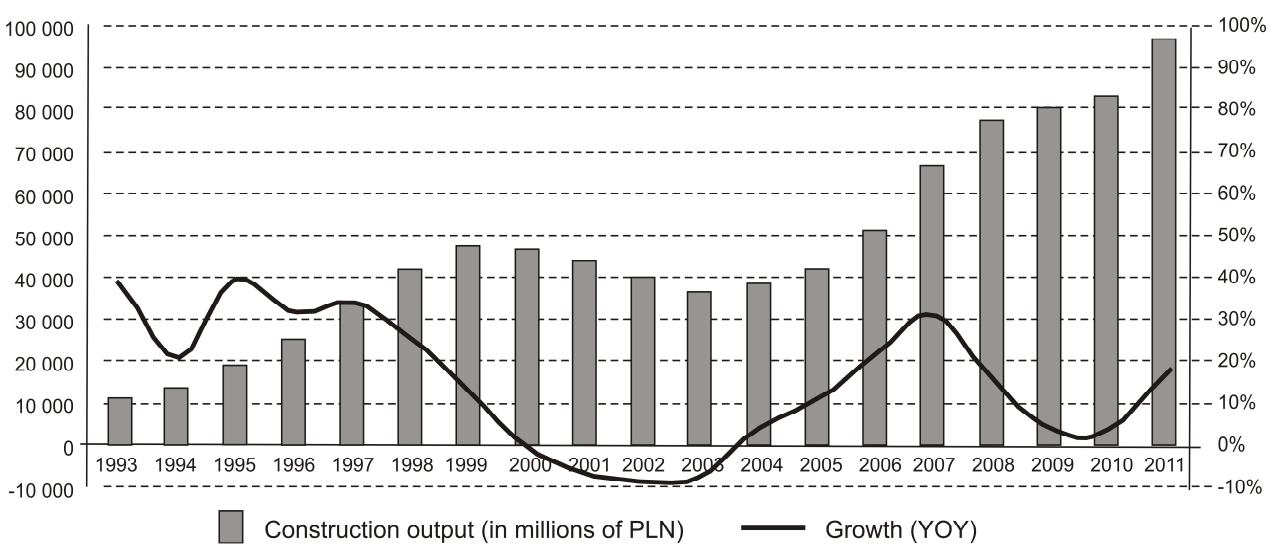

Figure 3. Value of the Construction Output in Poland in the years 1993-2011 Source: BDM (2014, p. 13).

The value of the civil engineering sector output in Poland in 2010 reached PLN 82.6 milliard (for entities employing 9+ staff), and its growth has reached and maintained a double-digit values since November 2010. This mainly resulted from a growth in expenditures on civil engineering projects (the peak of the public investments made through the General Directorate for National Roads and Motorways (GDDKiA) and investment projects related to Euro 2012) (Figure 4).

Approx. 60\% of construction output in Poland in 2010 was generated by the construction of non-enclosed structures, mainly roads, bridges and railways (these segments jointly accounted for $34 \%$ of the construction output in Poland in 2010). The investment projects were mainly financed from the state budget and EU funds, with concession sections of motorway as the only exception. On the other hand, the planned 
reduction in investment in roads and motorways affected the value of the Polish construction market in subsequent years.

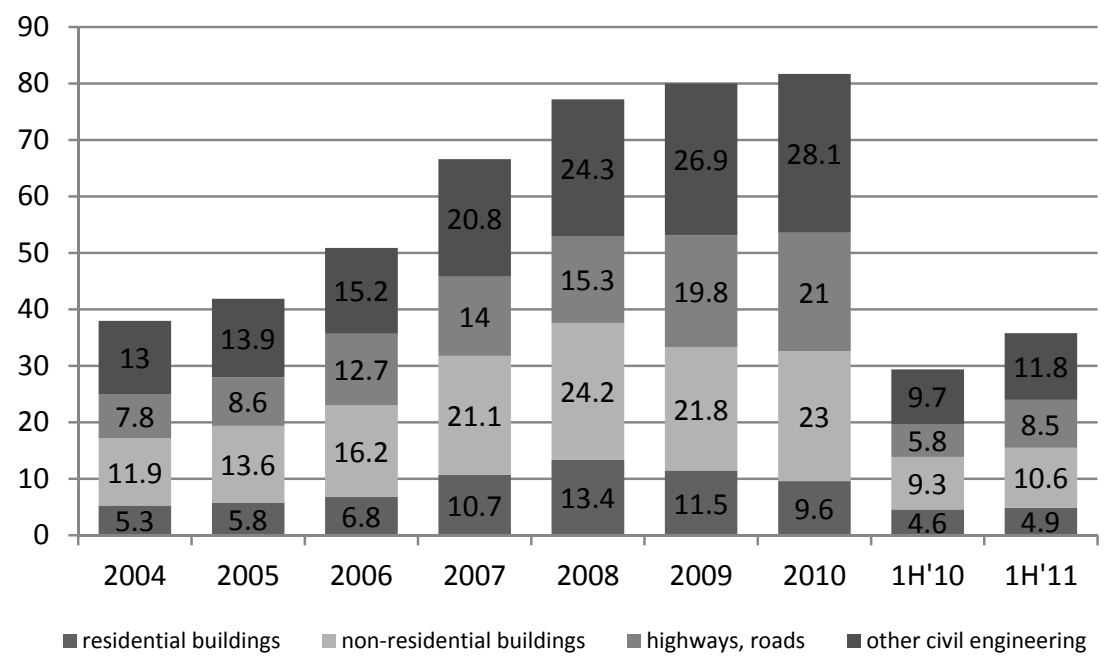

Figure 4. Structure of civil engineering output (in PLN milliard)

Source: BDM (2014, p. 20).

Table 2. Structure of the Polish construction sector, 2005-2011

\begin{tabular}{|c|c|c|c|c|c|c|c|c|}
\hline Buildings and structures & 2005 & 2006 & 2007 & 2008 & 2009 & 2010 & $1 H^{\prime} 10$ & $1 H^{\prime} 11$ \\
\hline \multicolumn{9}{|c|}{ The structure of the construction market in Poland (in milliard PLN) } \\
\hline Total & 42.0 & 50.8 & 66.7 & 77.2 & 80.0 & 81.7 & 29.4 & 35.7 \\
\hline Cubic construction total & 19.5 & 23.0 & 31.9 & 37.6 & 33.3 & 32.6 & 13.9 & 15.4 \\
\hline Residential buildings & 5.8 & 6.8 & 10.7 & 13.4 & 11.5 & 9.6 & 4.6 & 4.9 \\
\hline Civil and water engineering structures & 22.5 & 27.8 & 34.8 & 39.6 & 46.6 & 49.1 & 15.5 & 20.3 \\
\hline \multicolumn{9}{|c|}{ Change (YOY, in \%) } \\
\hline Total & - & 21 & 31 & 16 & 4 & 2 & - & 21 \\
\hline Cubic construction total & - & 18 & 38 & 18 & -11 & -2 & - & 11 \\
\hline Residential buildings & - & 17 & 58 & 25 & -14 & -17 & - & 6 \\
\hline Civil and water engineering structures & - & 24 & 25 & 14 & 18 & 5 & - & 31 \\
\hline \multicolumn{9}{|c|}{ Structure (in \%) } \\
\hline Total & 100 & 100 & 100 & 100 & 100 & 100 & 100 & 100 \\
\hline Cubic construction structures & 46 & 45 & 48 & 49 & 42 & 40 & 47 & 43 \\
\hline Residential buildings & 14 & 13 & 16 & 17 & 14 & 12 & 16 & 14 \\
\hline Civil and water engineering structures & 54 & 55 & 52 & 51 & 58 & 60 & 53 & 57 \\
\hline
\end{tabular}

Source: adapted from (BDM, 2014, p. 23).

In 2011, the housing sector accounted for $11-12 \%$ of the construction market in Poland. From construction companies' perspective, the market is highly competitive, dominated by smaller entities. A considerable drop in the value of investment projects was observed in 2009 and 2010, while 2011 saw a recovery. In the period between the third quarter of 2010 and the second quarter of 2011, 37000 new dwellings were offered on the market. It was 5,000 more than in in the entire 2008, when an abrupt 
growth had been observed in this segment. However, note that the housing standard in Poland expressed, for instance, as the number of dwellings per 1000 inhabitants is relatively low. The above-mentioned indicator for Poland is 348 against 500 in the majority of Western European countries. Polish dwellings are smaller in size and overcrowded. It is estimated that over $50 \%$ of the Poles live in overcrowded dwellings as for the EU-27, Poland came only before Hungary and Romania, with the EU average at nearly 18\% (Housing Europe Review 2011, pp. 13-16).

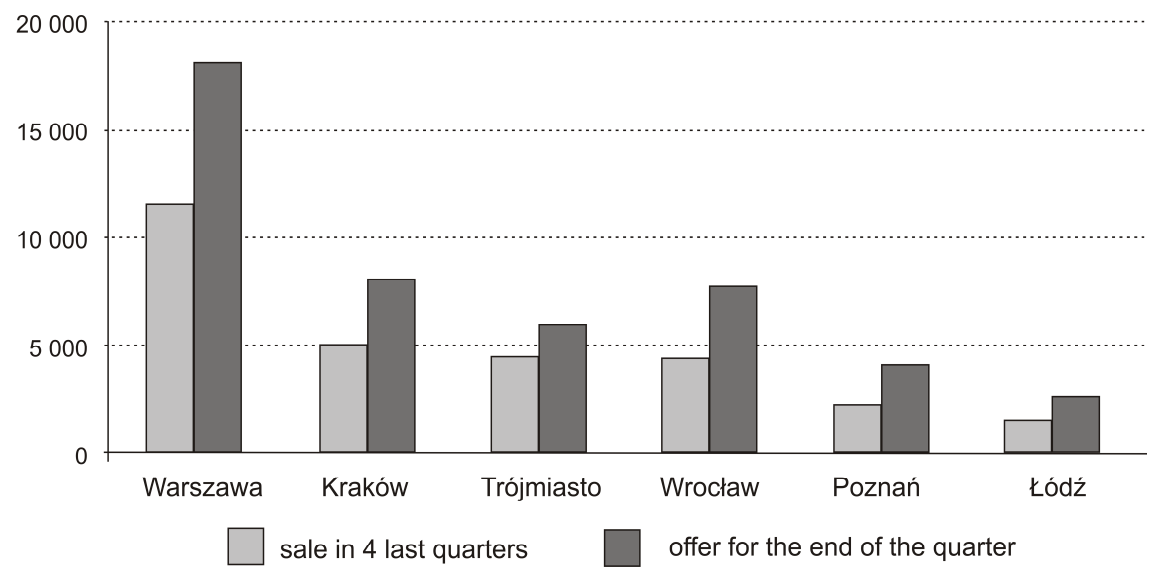

Figure 5. Key markets in the housing segment of the construction sector, 2Q-2011 Source: own study based on BDM (2014, p. 20).

In 2012, the Polish construction market cherished a rather positive outlook due to prolongation or postponement of the implementation of public contracts, but 2013-2015 outlook is bleak, mainly because of a gap resulting from the lower value of contracts offered under tender procedures in 2011-2012 (both, the decrease of public financing as well as suspension of commercial projects).

Factors having particular adverse effect on the condition of the Polish construction sector include: fierce competition, poor condition of public finance, a planned significant reduction of investment into transport infrastructure, deteriorating economic condition, uncertainty as to available financing of infrastructural projects in the next EU budget and payment gridlocks.

The above analyses may be supplemented and supported with the findings of the surveys conducted by CEEC Research in collaboration with KPMG in Poland and with a data collection company Norstat Polska (BDM, 2014, pp. 5-10). The surveys were conducted among managing directors and members of management boards of construction companies with a view to evaluating the condition of the construction industry in Poland compared with other countries of the Visegrad Group. The surveys show moods and expectations concerning the condition of the construction sector (Table 3).

The findings suggest continuation of a downward trend in the output of the Polish construction sector. According to forecasts, the drop may be the largest among all V4 countries and may even reach $11 \%$. Similar are the forecasts concerning the sales 
planned in 2013. According to more than a half of the respondents (59\%), the sales will fall by $6.1 \%$. For comparison, in the Czech Republic a small increase in sale is expected (+0.6\%). Only 38\% Polish companies expect to improve their market position in 2013. The surveys show clearly that the level of optimism among Polish construction sector companies is rather low - the lowest of all Visegrad Group countries.

Table 3. Situation in the construction sector in Visegrad Group countries (in \%)

\begin{tabular}{|l|r|r|r|r|}
\hline \multicolumn{1}{|c|}{$\begin{array}{c}\text { Selected factors describing } \\
\text { situation } \\
\text { in the construction sector }\end{array}$} & $\begin{array}{c}\text { Czech Republic } \\
\text { survey } \\
\text { Feb. 2013 }\end{array}$ & $\begin{array}{c}\text { Slovakia } \\
\text { survey } \\
\text { Mar. 2013 }\end{array}$ & $\begin{array}{c}\text { Hungary } \\
\text { survey } \\
\text { Jun. 2012 }\end{array}$ & $\begin{array}{c}\text { Poland } \\
\text { Survey } \\
\text { Mar-Apr. 2013 }\end{array}$ \\
\hline $\begin{array}{l}\text { Construction sector growth, 2013 } \\
\text { (own forecast of the sector) }\end{array}$ & -4.4 & -4.6 & -2.2 & -11.0 \\
\hline $\begin{array}{l}\text { Change in sales 2013 } \\
\text { (managers' forecast) }\end{array}$ & +0.6 & -3.3 & -2.3 & -6.1 \\
\hline $\begin{array}{l}\text { Companies anticipating } \\
\text { improvement } \\
\text { of their market standing in 2013 }\end{array}$ & 59.0 & 46.0 & 51.0 & 38.0 \\
\hline $\begin{array}{l}\text { Average use of production } \\
\text { capacities }\end{array}$ & 65.0 & 63.0 & 59.0 & 60.0 \\
\hline
\end{tabular}

Source: adapted from BDM (2014, pp. 5-10).

\section{Analysis of the Housing Segment in Czech Republic, Poland and in Selected Regions}

The authors prepared the analysis of the present situation and of the growth of the both countries and selected regions. In Czech Republic these regions were: Moravia Silesia, Olomouc, Southern Moravia, Zlín; while in Poland - the Małopolska Region. The analysis covered the years 2006-2012 - the time before the economic crisis and during the crisis. The size of the housing segment in Poland and in Czech Republic as well as in individual regions was determined on the basis of completed new dwellings per 1000 inhabitants. The choice of the regions in Czech Republic and in Poland was not accidental. The authors support it by claiming their familiarity with the areas and certain similarities of the areas - the four regions selected in the Czech Republic have similar population potential to the Małopolska Region, higher than average population density, they are situated far from their respective capital cities and are borderland regions (MRD, 2005; UMWM, 2012). Both countries and all analysed regions differ in terms of saturation with dwellings, expressed as the number of dwellings per 1000 inhabitants or usable floor area per person (Table 4).

In the analysed period, Poland's condition in the housing segment measured by new dwellings completed per 1000 persons was better than in the Czech Republic both in the year 2006 - at the beginning of the analysed period - as well as in 2012 closing the period, showing an upward trend. In 2006 and 2012, the indicator for Poland reached: 3.0 and 4.0 completed dwellings per 1,000 inhabitants, respectively; while in the Czech Republic it was 2.9 and 2.8, respectively. For the four analysed Czech regions, the ratio was: 2.3 . and 2.5 respectively; however, the values above the country's average were recorded only in the Southern Moravia Region (3.5 and 3.2 respectively). As regards the Małopolska Region, the recorded values were significantly above the country's average 3.8 and 4.6, respectively. In terms of growth in the period 2006-2012, the number of new dwellings completed in Czech Republic was sloping (-2.4\%), while in Poland, in the same 
period, it was soaring (32.6\%). In the same time, a high positive growth was reported in Poland (nearly 33\%), with a fairly good result in the Małopolska Region (23\%); still below the country's average (Table 5 and 6).

Table 4. Population potential and housing segment in selected regions of the Czech Republic and Poland in 2012

\begin{tabular}{|c|c|c|c|c|}
\hline Country/region & Population & $\begin{array}{c}\text { Population } \\
\text { density } \\
\text { (persons } / 1 \mathrm{~km}^{2} \text { ) }\end{array}$ & $\begin{array}{c}\text { Dwellings } \\
\text { per 1,000 } \\
\text { inhabitants }\end{array}$ & $\begin{array}{l}\text { Usable floor } \\
\text { area in } m^{2} \\
\text { per person }\end{array}$ \\
\hline 1. Czech Republic & 10516125 & 133 & 452 & 25.5 \\
\hline 2. Moravia-Silesia Region & 1226602 & 226 & 434 & \\
\hline 3. Olomouc Region & 637609 & 121 & 438 & 32.2 \\
\hline 4. South Moravia Region & 1168650 & 162 & 431 & 31.4 \\
\hline 5. Zlín Region & 587693 & 148 & 429 & 31.4 \\
\hline $2+3+4+5$ & 3620554 & 164 & 433 & \\
\hline 6. Poland & 38125479 & 123 & 356 & 25.9 \\
\hline 7. The Małopolska Region & 2524651 & 221 & 329 & 24.9 \\
\hline
\end{tabular}

Source: own study based on the data of the Czech Statistical Office, Central Statistical Office.

Table 5. Growth of completed dwellings in the Czech Republic, 2006-2012

\begin{tabular}{|c|c|c|c|c|c|}
\hline Region & $\begin{array}{l}\text { Completed } \\
\text { dwellings } \\
2006\end{array}$ & $\begin{array}{l}\text { Completed } \\
\text { dwellings } \\
2012\end{array}$ & $\begin{array}{c}\text { Completed } \\
\text { dwellings per } 1000 \\
\text { inhabitants } 2006\end{array}$ & $\begin{array}{c}\text { Completed } \\
\text { dwellings per } \\
1000 \text { inhabitants } \\
2012\end{array}$ & $\begin{array}{l}\text { Completed } \\
\text { dwellings } \\
\text { growth 2006- } \\
2012 \text { (in \%) }\end{array}$ \\
\hline Central Bohemia & 5957 & 5900 & 5.1 & 4.6 & -1.0 \\
\hline Hradec Králové & 1218 & 1384 & 2.2 & 2.5 & 13.6 \\
\hline Karlovy Vary & 638 & 543 & 2.1 & 1.8 & -14.9 \\
\hline Liberec & 1024 & 1252 & 2.4 & 2.9 & 22.3 \\
\hline Moravia-Silesia & 1632 & 2698 & 1.3 & 2.2 & 65.3 \\
\hline Olomouc & 1307 & 1490 & 2.0 & 2.3 & 14.0 \\
\hline Pardubice & 1515 & 1295 & 3.0 & 2.5 & -14.5 \\
\hline Plzeň & 2067 & 1444 & 3.7 & 2.5 & -30.1 \\
\hline Prague & 5186 & 4024 & 4.4 & 3.2 & -22.4 \\
\hline South Bohemia & 1909 & 1983 & 3.0 & 3.1 & 3.9 \\
\hline South Moravia & 3985 & 3770 & 3.5 & 3.2 & -5.4 \\
\hline Ústi & 1119 & 1271 & 1.4 & 1.5 & 13.6 \\
\hline Vysočina & 1495 & 1276 & 2.9 & 2.5 & -14.6 \\
\hline Zlín & 1138 & 1137 & 1.9 & 1.9 & -0.1 \\
\hline Czech Republic & 30190 & 29467 & 2.9 & 2.8 & -2.4 \\
\hline
\end{tabular}

Source: own study based on the data of Czech Statistical Office.

While the growth reported between 2006 and 2012 in both countries differs, being negative in Czech Republic and positive in Poland, the year on year trend was similar for both of them, demonstrated a delayed impact of the economic crisis when compared to other economy sectors. In the construction industry, including the housing segment, both in the Czech Republic and in Poland a decrease in the output measured as the number of completed dwellings was recorded in 2009, with the worst results were in 2010 and 2011. In 2012, the number of new completed dwellings went up (Figure 6 and 7). 
Table 6. Growth in the number of completed dwellings in Poland in the years 2006-2012

\begin{tabular}{|l|r|r|r|r|r|}
\hline \multicolumn{1}{|c|}{ Region } & $\begin{array}{c}\text { Completed } \\
\text { dwellings } \\
\mathbf{2 0 0 6}\end{array}$ & $\begin{array}{c}\text { Completed } \\
\text { dwellings } \\
\mathbf{2 0 1 2}\end{array}$ & $\begin{array}{l}\text { Completed } \\
\text { dwellings } \\
\text { per 1000 } \\
\text { inhabitants } \\
\text { 2006 }\end{array}$ & $\begin{array}{c}\text { Completed } \\
\text { dwellings } \\
\text { per 1000 } \\
\text { inhabitants } \\
\mathbf{2 0 1 2}\end{array}$ & $\begin{array}{c}\text { Completed } \\
\text { dwellings } \\
\text { growth 2006- } \\
\mathbf{2 0 1 2} \text { (in \%) }\end{array}$ \\
\hline Dolnośląskie & 9167 & 15028 & 3.2 & 5.2 & 63.9 \\
\hline Kujawsko-pomorskie & 5006 & 6358 & 2.4 & 3.0 & 27.0 \\
\hline Lubelskie & 4780 & 7190 & 2.2 & 3.3 & 50.4 \\
\hline Lubuskie & 2918 & 3169 & 2.9 & 3.1 & 8.6 \\
\hline tódzkie & 4868 & 8019 & 1.9 & 3.2 & $\mathbf{2 3 . 3}$ \\
\hline Małopolskie & $\mathbf{1 2 4 0 5}$ & $\mathbf{1 5 2 9 4}$ & $\mathbf{3 . 8}$ & $\mathbf{4 . 6}$ & 12.8 \\
\hline Mazowieckie & 27090 & 30554 & 5.2 & 5.8 & 36.0 \\
\hline Opolskie & 1338 & 1820 & 1.3 & 1.8 & 40.3 \\
\hline Podkarpackie & 4652 & 6526 & 2.2 & 3.1 & 49.0 \\
\hline Podlaskie & 3036 & 4525 & 2.5 & 3.8 & 17.7 \\
\hline Pomorskie & 10018 & 14194 & 4.5 & 6.2 & 91.9 \\
\hline Śláskie & 8325 & 9744 & 1.8 & 2.1 & 23.0 \\
\hline Świętokrzyskie & 1614 & 3097 & 1.3 & 2.4 & 40.4 \\
\hline Warmińsko-mazurskie & 4469 & 5496 & 3.1 & 3.8 & 38.3 \\
\hline Wielkopolskie & 10549 & 14811 & 3.1 & 4.3 & 32.6 \\
\hline Zachodniopomorkie & 5118 & 7079 & 3.0 & 4.1 & 4.0 \\
\hline Poland & 115353 & 152904 & 3.0 & &
\end{tabular}

Source: own study based on the data of the Central Statistical Office of Poland.

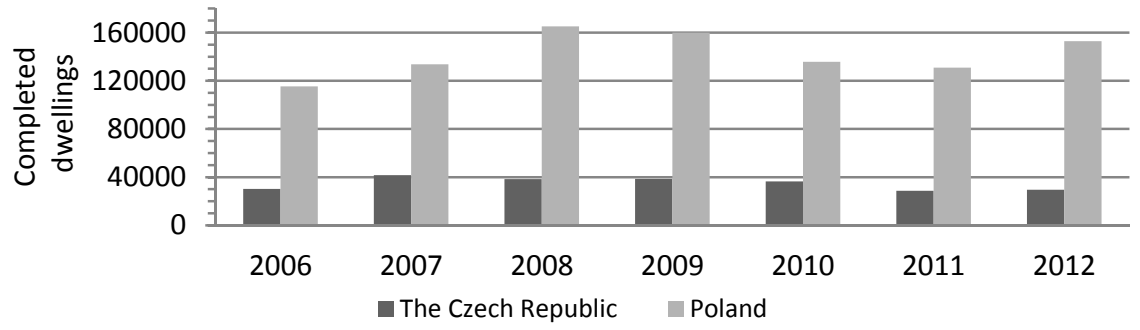

Figure 6. Dwellings completed in the Czech Republic and in Poland, 2006-2012

Source: own study based on the Czech Statistical Office, Central Statistical Office of Poland.

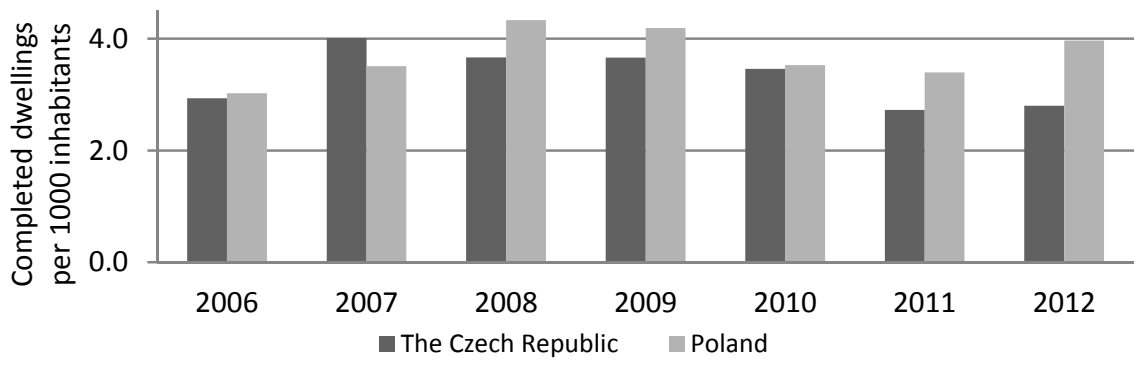

Figure 7. Dwellings completed per 1000 inhabitants

in the Czech Republic and Poland in 2006-2012

Source: own study based on Czech Statistical Office, Central Statistical Office of Poland. 
The negative growth in the number of dwellings completed in Czech Republic did not translate directly into the growth in the analysed regions. Two such regions reported a significant positive growth: the Moravia-Silesia Region (growth in excess of 65\%) and the Olomouc Region (14\%). On the other hand, two other regions reported a negative growth. The Zlín Region's growth was slightly in the red $(-0.1 \%)$, while the South Moravia Region's growth (-5.4\%) was rather pessimistic (Figure 8).

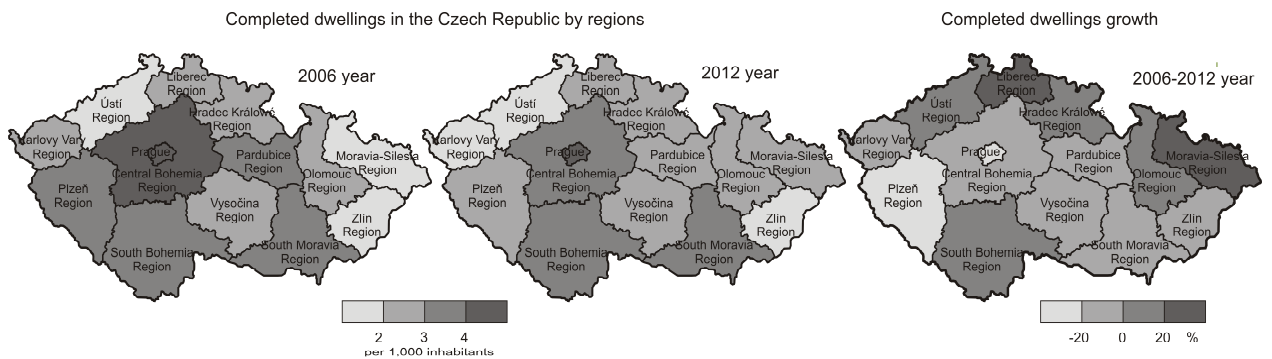

Figure 8. Growth of the dwelling segment in the Czech Republic, 2006-2012

Source: own study based on the Czech Statistical Office.

Note that both Poland and Czech Republic reported a higher growth in the number of completed dwellings in the regions generating relatively low number of dwellings completed per 1000 inhabitants in the first year of the analysed period (Table 5 and 6, Figure 8 and 9).
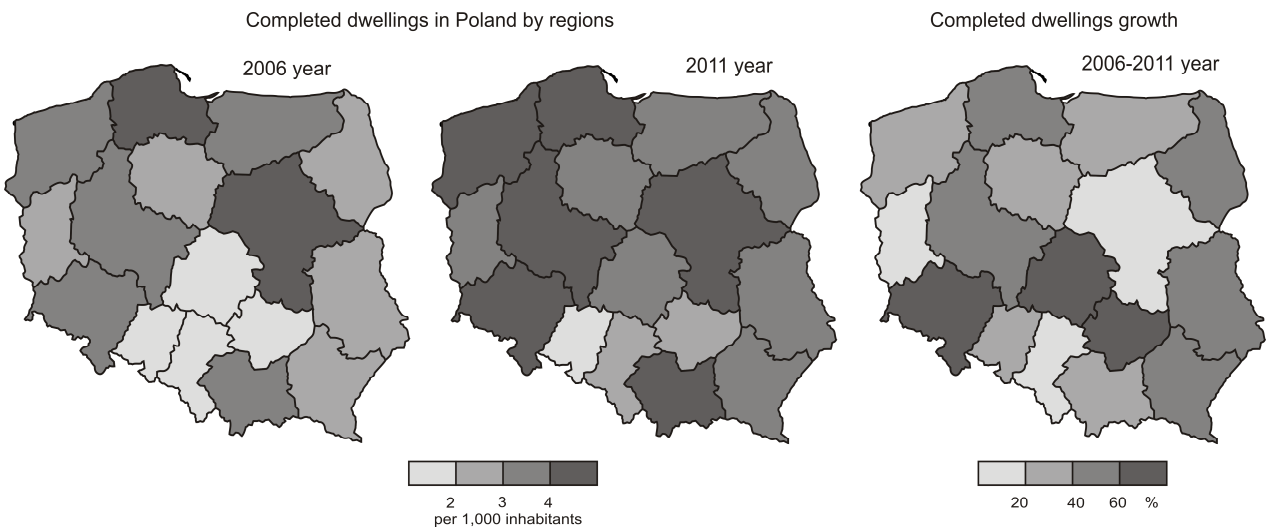

Figure 9. Growth of the dwelling segment in Poland, 2006-2012

Source: own study based on the Central Statistical Office of Poland.

In case of the Czech Republic, the above-discussed Moravia-Silesia Region or Ústi Region may serve as examples of regions with the lowest number of dwellings completed per 1000 inhabitants indicator in 2006, hand in hand with the above-mentioned Olomouc Region and Liberec Region. On the other hand, regions reporting significantly higher values of the indicator in 2006 showed a negative growth, including: the capital region of Prague reporting $-22 \%$ of the growth and the region surrounding the city of Prague. What is interesting, the Central Bohemia Region around Prague also suffered 
from a slight negative growth (-1\%) while it reported 5.1 dwellings completed per 1000 inhabitants back in 2006. Apart from Prague, a significant decrease of the indicator was reported by the Plzeň Region (-30\%) (Figure 8).

No such negative growth was reported for Poland in regional comparisons, as mentioned above, the highest negative growth was reported for the regions showing the lowest initial values of the indicator, including: the Opolskie and Łódzkie Regions as well as the region along the eastern border of Poland, including: the Świętokrzyskie, Podlaskie, Lubelskie and Podkarpackie Regions, with the initial indicator in the range from 1.3 to 2.5 and the growth from $40 \%$ to $50 \%$, including the Świętokrzyskie Region growing at the rate in excess of $90 \%$. While the capital Mazowieckie Region reported a positive growth, contrary to the capital region of the Czech Republic, note that the growth ranked among the lowest (slightly below 13\%) when compared to the highest value of the indicator (5.2\%) among all regions in Poland (Figure 9).

Inside regions, the above-described regularity consisting in compensating a shortage on the housing segment with an increased growth in areas reporting the lowest growth in the number of completed dwellings per 1000 inhabitants in the initial year 2006 becomes even clearer for smaller territorial units - districts in the Czech Republic and poviats in Poland.

Table 7. Growth in dwellings completed in some Czech regions, 2006-2012

\begin{tabular}{|c|c|c|c|c|c|c|}
\hline Region & District & $\begin{array}{c}\text { Completed } \\
\text { dwellings } \\
2006\end{array}$ & $\begin{array}{c}\text { Completed } \\
\text { Odwellings } \\
2012\end{array}$ & $\begin{array}{c}\text { Completed } \\
\text { dwellings } \\
\text { per } 1000 \\
\text { inhabitants } \\
2006\end{array}$ & $\begin{array}{c}\text { Completed } \\
\text { dwellings } \\
\text { per } 1000 \\
\text { inhabitants } \\
2012\end{array}$ & $\begin{array}{c}\text { Completed } \\
\text { dwellings growth } \\
\text { 2006-2012\% }\end{array}$ \\
\hline \multirow{7}{*}{$\begin{array}{l}\text { South } \\
\text { Moravia } \\
\text { Region }\end{array}$} & Blansko & 574 & 319 & 5.3 & 3.0 & -44.4 \\
\hline & Znojmo & 404 & 290 & 3.5 & 2.6 & -28.2 \\
\hline & Vyškov & 312 & 273 & 3.6 & 3.0 & -12.5 \\
\hline & Brno-město & 1443 & 1342 & 3.9 & 3.5 & -7.0 \\
\hline & Brno-venkov & 808 & 903 & 4.6 & 4.3 & 11.8 \\
\hline & Hodonín & 244 & 331 & 1.6 & 2.1 & 35.7 \\
\hline & Břeclav & 200 & 312 & 1.6 & 2.7 & 56.0 \\
\hline \multirow{6}{*}{$\begin{array}{l}\text { Moravia- } \\
\text { Silesia }\end{array}$} & Bruntál & 136 & 133 & 1.4 & 1.4 & -2.2 \\
\hline & Nový Jičín & 293 & 304 & 1.8 & 2.0 & 3.8 \\
\hline & Opava & 304 & 469 & 1.7 & 2.6 & 54.3 \\
\hline & Frýdek-Místek & 431 & 730 & 1.9 & 3.4 & 69.4 \\
\hline & Karviná & 204 & 414 & 0.7 & 1.6 & 102.9 \\
\hline & Ostrava-město & 264 & 648 & 0.9 & 2.0 & 145.5 \\
\hline \multirow{5}{*}{ Olomouc } & Prostějov & 373 & 287 & 3.4 & 2.6 & -23.1 \\
\hline & Jeseník & 109 & 112 & 2.6 & 2.8 & 2.8 \\
\hline & Olomouc & 588 & 708 & 2.6 & 3.0 & 20.4 \\
\hline & Šumperk & 114 & 175 & 0.9 & 1.4 & 53.5 \\
\hline & Přerov & 123 & 208 & 0.9 & 1.6 & 69.1 \\
\hline \multirow{4}{*}{ Zlín } & Zlín & 384 & 282 & 2.0 & 1.5 & -26.6 \\
\hline & Vsetín & 326 & 345 & 2.2 & 2.4 & 5.8 \\
\hline & Uherské Hradiště & 306 & 362 & 2.1 & 2.5 & 18.3 \\
\hline & Kroměříž & 122 & 148 & 1.1 & 1.4 & 21.3 \\
\hline \multicolumn{2}{|l|}{ Total } & 8062 & 9095 & 2,7 & 2.5 & 12.8 \\
\hline
\end{tabular}

Source: own study based on the Czech Statistical Office. 
Therefore, in two Czech regions reporting an overall positive growth (MoraviaSilesia and Olomouc), districts reporting the highest growth (even in excess of 100 and $140 \%)$ reported the initial values of the indicator below 1.0. The lowest growth of $-44 \%$ was reported by Blansko district in the South Moravia Region, which had reported the highest value of 5.3 of the indicator in 2006 of all the analysed districts (Table 7, Figure 10).

Similarly, in the case of the Małopolska Region, poviats reporting low initial indicators reported high growths. On the one hand, these were typical rural poviats or poviats located far from large urban areas, e.g. poviats reporting the highest growth in the region: Miechowski (nearly 327\%), Nowosądecki (176\%), Bocheński (107\%), Dąbrowski (nearly 94\%), as well as poviats in the vicinity of the main city in the region, Kraków, in particular Wielicki Poviat which has been rapidly growing (107\%) (Table 8, Figure 11) (compare: Szymańska \& Płaziak, 2014, p. 387).
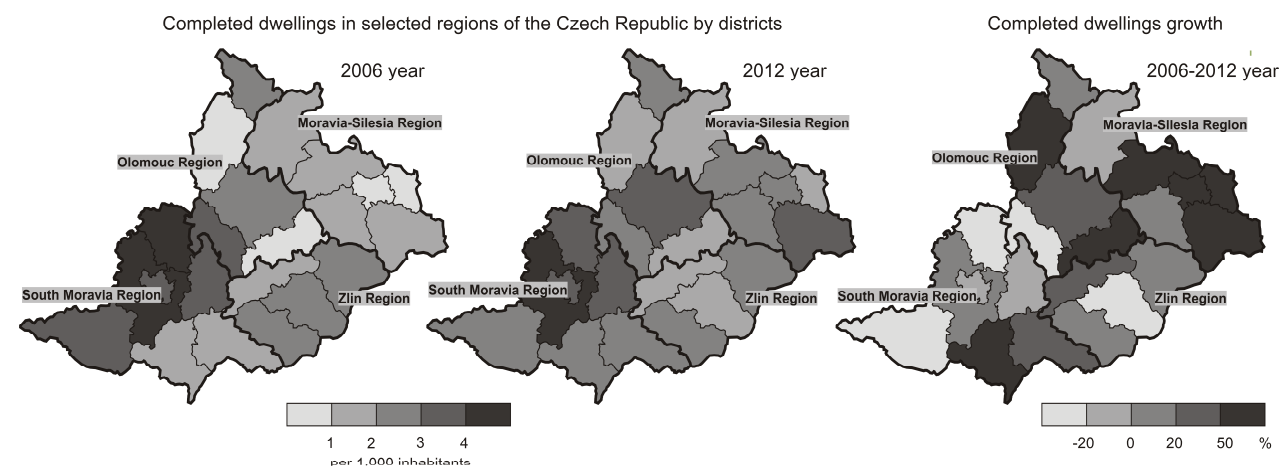

Figure 10. Growth of the dwelling segment in some Czech regions, 2006-2012 Source: own study based on the Czech Statistical Office.

Summarising the above-presented analysis, the authors conclude that the abovepresented comparison shows a significantly higher growth of the dwelling segment in Poland. Note that no region in Poland reported a negative growth in the analysed period. A direct cause of such development may be higher saturation of the Czech dwelling segment, expressed by the number of dwellings per 1000 inhabitants' indicator and by the usable floor space of dwellings per 1 inhabitant.

Typically, positive growth was reported for entities (in regions, districts or poviats) with the lowest dwelling (or usable dwelling floor space) saturation in 2006. And viceversa: a negative or low growth of the market was reported by entities with the highest initial values, including the city of Prague and its surrounding districts.

In the context of regions and their districts/poviats, there was a trend on the dwelling segment consisting in the housing segment moving to the outskirts which so far had not been highly saturated in terms of demand for dwelling. On the other hand, the Małopolska Region continues to demonstrate a growing demand for new dwellings in the vicinity of Krakow, as remarkably demonstrated by Wielicki Poviat (Raźniak \& BrzoskoSermak, 2014; Raźniak \& Winiarczyk-Raźniak, 2014). 
Table 8. Growth in dwellings completed in the Małopolska Region, 2006-2012

\begin{tabular}{|c|c|c|c|c|c|}
\hline Poviat & $\begin{array}{c}\text { Completed } \\
\text { dwellings } \\
2006\end{array}$ & $\begin{array}{c}\text { Completed } \\
\text { dwellings } \\
2012\end{array}$ & $\begin{array}{c}\text { Completed } \\
\text { dwellings per } \\
1000 \text { inhabitants } \\
2006\end{array}$ & $\begin{array}{c}\text { Completed } \\
\text { dwellings per } \\
1000 \text { inhabitants } \\
2012\end{array}$ & $\begin{array}{c}\text { Completed } \\
\text { dwellings } \\
\text { growth 2006- } \\
2012 \%\end{array}$ \\
\hline Chrzanowski & 192 & 197 & 1.5 & 1.5 & 2.6 \\
\hline Oświęcimski & 370 & 380 & 2.4 & 2.5 & 2.7 \\
\hline Kraków & 6612 & 6824 & 8.7 & 9.0 & 3.2 \\
\hline Wadowicki & 365 & 397 & 2.4 & 2.5 & 8.8 \\
\hline Gorlicki & 222 & 262 & 2.1 & 2.4 & 18.0 \\
\hline Tatrzański & 235 & 278 & 3.6 & 4.1 & 18.3 \\
\hline Nowotarski & 395 & 488 & 2.2 & 2.6 & 23.5 \\
\hline Olkuski & 207 & 267 & 1.8 & 2.3 & 29.0 \\
\hline Suski & 265 & 351 & 3.2 & 4.2 & 32.5 \\
\hline Brzeski & 201 & 268 & 2.2 & 2.9 & 33.3 \\
\hline Tarnów & 333 & 449 & 2.8 & 4.0 & 34.8 \\
\hline Krakowski & 895 & 1231 & 3.6 & 4.7 & 37.5 \\
\hline Proszowicki & 53 & 73 & 1.2 & 1.7 & 37.7 \\
\hline Nowy Sącz & 246 & 341 & 2.9 & 4.1 & 38.6 \\
\hline Limanowski & 207 & 315 & 1.7 & 2.5 & 52.2 \\
\hline Myślenicki & 290 & 448 & 2.5 & 3.6 & 54.5 \\
\hline Tarnowski & 417 & 681 & 2.2 & 3.4 & 63.3 \\
\hline Dąbrowski & 78 & 151 & 1.3 & 2.5 & 93.6 \\
\hline Bocheński & 196 & 406 & 1.9 & 3.9 & 107.1 \\
\hline Wielicki & 384 & 796 & 3.6 & 6.8 & 107.3 \\
\hline Nowosądecki & 227 & 627 & 1.1 & 3.0 & 176.2 \\
\hline Miechowski & 15 & 64 & 0.3 & 1.3 & 326.7 \\
\hline Total & 12405 & 15294 & 3.8 & 4.6 & 23.3 \\
\hline
\end{tabular}

Source: own study based on: the Central Statistical Office of Poland.
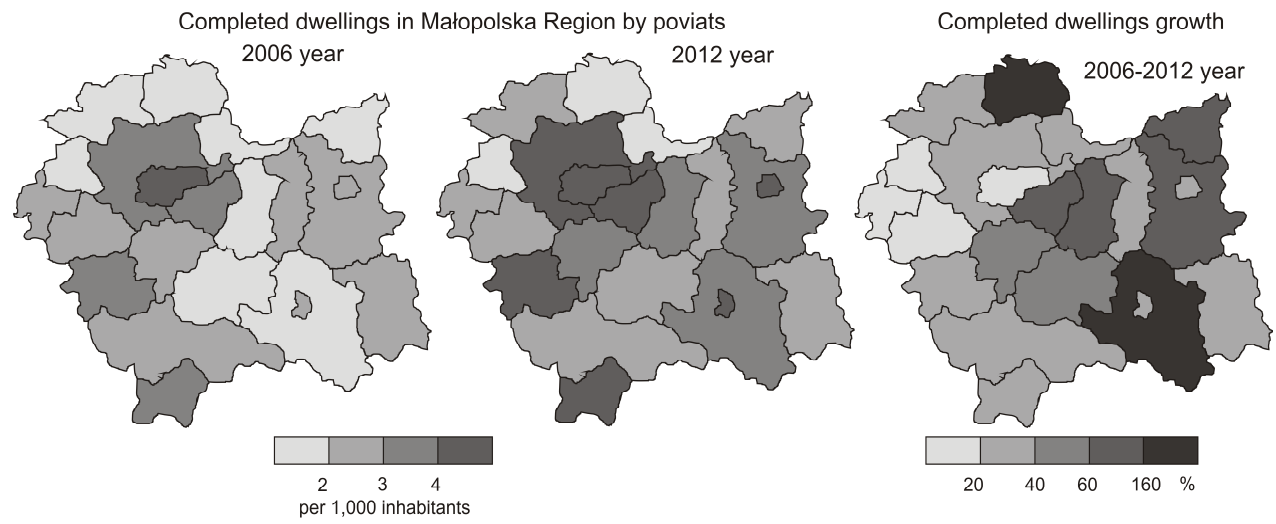

Figure 11. Growth of the dwelling segment in the Małopolska Region, 2006-2012

Source: own study based on the Central Statistical Office of Poland.

\section{CONCLUSIONS}

The construction sector forms an important part of both Czech and Polish economy. It is also very sensitive to the economic condition. On the other hand, the construction market shows delays in its reactions to changing market conditions. The 
observed delayed reaction to the most recent global crisis (Rachwat, 2011, pp. 99-113) was related to the specificity of the sector with numerous long-term investment projects, often initiated in the period before the crisis hit.

In the condition of the global economic crisis, the construction production fluctuation trend for both countries was similar, reporting the least favourable indicators in 2010 and 2011. In their analysis of the construction sector, the authors focused on the dwelling segment. While the above-mentioned trends were similar for both countries during the crisis, Czech Republic reported a negative growth $(-2.4 \%)$ in the number of completed dwellings in the period while Poland reported a positive growth of $32.6 \%$. The discrepancies can be explained by differences in the demographic potential of both countries (the Czech market is markedly smaller because of significantly smaller population of Czech Republic) and reports higher saturation of the dwelling segment.

When comparing regions and local trends, similarities were reported such as intensified housing investment in areas where such investment projects had been scarce or non-existent. In case of Czech Republic, these were: Moravia-Silesia and Olomouc, in Poland - regions along the eastern border of Poland. Furthermore, dwelling investment projects shrank in regions reporting the highest indicators in 2006, including the region of Prague and its surrounding Central Bohemia Region. Furthermore, the trend is more distinctive for Czech Republic than for Poland.

As indicated above, the construction sector is sensitive to fluctuations and changes in the economic condition (Gorzelak, 2009). It is also sensitive to other conditions, even such as an insufficient demand mentioned in the paper, as well as the weather conditions, inadequate and insufficient labour force, high labour costs, red tape, competition, etc. One cannot underestimate politics which may inhibit or facilitate development of the sector. In case of the construction sector and the housing construction sector in particular, in the future the policy of the EU accompanied by the energy requirements for newly built houses and guidelines in this respect may slow down the growth. By 2020, in the EU states, the construction sector must comply with low-energy standards in the housing sector. This requirement is certain to generate much higher construction costs (Płaziak, 2013a, pp. 173-188; 2013b, pp. 214-226).

\section{REFERENCES}

BAA (2011). Sektor budowlany w czasie i przestrzeni. Ocena standingu adaptacyjności sektora. Grupa Doradców Biznesowych BAA Polska.

BDB (2014). Budownictwo, Dom Maklerski BDM S.A. Retrieved on January 11, 2014, from http://www.bdm.com.pl/

Borowiec, M. \& Dorocki, S., (2011). Rola kapitału ludzkiego w procesie kształtowania innowacyjności układów regionalnych Francji. In B. Namyślak (ed.), Przekształcenia regionalnych struktur funkcjonalno-przestrzennych. Wrocław: Instytut Geografii i Rozwoju Regionalnego Uniwersytetu Wrocławskiego, pp. 215-230.

Budownictwo mieszkaniowe w Republice Czeskiej. Retrieved on January 11, 2014, from http://praha.trade.gov.pl/pl/aktualnosci/article/y,2011,m,6,a,17220,Budownictwo_mieszka niowe_w_Republice_Czeskiej.html

Czech Statistical Office, Retrieved on January 11, 2014, from http://www.czso.cz/eng/redakce .nsf/i/construction_ekon 
Gorzelak, G. (2009). Geografia polskiego kryzysu. Kryzys peryferii czy peryferia kryzysu? Regional Studies Association - Sekcja Polska, Warszawa.

Housing Europe Review, The Nuts and Bolts of European Social Housing Systems (2012). CECODHAS Housing Europe's Observatory, Brussels.

Informacja o sytuacji społeczno-gospodarczej kraju rok 2011 (2012). Warszawa: Central Statistical Office.

Information on the Polish construction industry for the years 2012-2013, Retrieved on January 11, 2014, from http://www.polskie-budownictwo.pl

Kozik, R., \& Starzyk, E. (2011). Wpływ światowego kryzysu gospodarczego na polski rynek zamówień publicznych na roboty budowlane, Budownictwo i inżynieria środowiska, 2.

KPB (2012). Rynek budownictwa w Polsce oraz analiza rynków zagranicznych w zakresie możliwości eksportowych polskiej branży budowlanej. Łódź: Konsorcjum Polskie Budownictwo.

MRD (2005). Czech Republic. Portraits of Regions 2005. Prague: Ministry for Regional Development of the Czech Republic.

Płaziak, M., \& Szymańska, A.I. (2014). Importance of personal factor in decisions on locating enterprises. Procedia - Social and Behavioral Sciences, 110, 373-380.

Płaziak, M. (2004a). The spatial distribution of living standards in the małopolskie province. Prace Geograficzne, 114, 107-116.

Płaziak, M. (2004b). Poziom życia ludności miast województwa małopolskiego, ze szczególnym uwzględnieniem miast małych i najmniejszych. In I. Jażdżewska (Ed.), Zróżnicowanie warunków życia ludności w mieście (pp. 121-129). XVII Konwersatorium Wiedzy o Mieście, Łódź, pp. 121-129.

Płaziak, M. (2013a). Domy energooszczędne i pasywne jako nieunikniona przyszłość budownictwa w Polsce. Prace Komisji Geografii Przemysłu Polskiego Towarzystwa Geograficznego, 21, 173188.

Płaziak, M. (2013b). Technologia tanich domów energooszczędnych jako odpowiedź na kryzys w budownictwie mieszkaniowym. Przedsiębiorczość - Edukacja, 9, 214-226.

Rachwał, T. (2011). Industrial restructuring in Poland and other European Union states in the era of economic globalization. Procedia - Social and Behavioral Sciences, 19, 1-10.

Rachwał, T. (2011). Wpływ kryzysu na zmiany produkcji przemysłowej w Polsce. Prace Komisji Geografii Przemysłu Polskiego Towarzystwa Geograficznego, 17, 99-113.

Raźniak, P., \& Brzosko-Sermak, A. (2014). Zmiany zasobów mieszkaniowych w regionie miejskim Krakowa. In E. Kaczmarska, \& P. Raźniak (Eds.), Społeczno-ekonomiczne i przestrzenne przemiany struktur regionalnych. Kraków: Oficyna Wydawnicza AFM.

Raźniak, P., \& Winiarczyk-Raźniak, A. (2014). Housing Conditions in selected metropolitan areas in Poland. Annales Universitatis Paedagogicae Cracoviensis Studia Geographica.

Szymańska, A.I., \& Płaziak, M. (2014). Factors considered in location of construction enterprises in the Małopolska Region. Procedia-Social and Behavioral Sciences, 110, 381-389.

UMWM, (2012). Województwo małopolskie 2012. Kraków: Urząd Marszałkowski Województwa Małopolskiego.

Zborowski, A. (2005). Przemiany struktury społeczno-przestrzennej regionu miejskiego w okresie realnego socjalizmu i transformacji ustrojowej (na przykładzie Krakowa), Kraków.

Zioło, Z. (2001). Współczesne tendencje rozwoju przemysłu i ich problematyka badawcza. Prace Komisji Geografii Przemysłu Polskiego Towarzystwa Geograficznego, 2, 9-20. 
Zioło, Z. (2008). Procesy transformacji przemysłowych układów przestrzennych na tle zmieniającego się otoczenia. Prace Komisji Geografii Przemysłu Polskiego Towarzystwa Geograficznego, 10, 11-22.

Zuzańska-Żyśko, E. (2014). The real estate market in the Upper-Silesian metropolitan area. Procedia-Social and Behavioral Sciences, 120, 374-385.

\title{
Authors
}

\section{Monika Płaziak}

$\mathrm{PhD}$ degree in economic geography, assistant professor in the Department of Entrepreneurship and Spatial Management, Institute of Geography, Pedagogical University of Cracow. Author's research interests concern issues of the spatial development in the context of the sustainable development - social balanced towns and energy-efficient towns, and also process of industrial and construction enterprises locations. As well as, research works refer to issues of the cooperation of scientific and research-developmental organizations with the SME sector, especially in the matter of the implementing new technologies and materials concerning the energy-efficient and passive building. Additionally, the author analyses issues of the level and quality of life, with particular reference to small and medium-sized towns in Poland.

\section{Anna Irena Szymańska}

PhD degree in economic sciences in the field of management sciences (Chair of Market Analysis and Marketing Research - Cracow University of Economics), assistant professor in the Department of Entrepreneurship and Spatial Management, Institute of Geography, Pedagogical University of Cracow. Her research interests are related to the issue of consumer needs, preferences and market behaviour as well as issues in the area of entrepreneurship and innovation with particular emphasis on the SME sector.

\author{
Correspondence to: \\ Monika Płaziak, PhD \\ Pedagogical University of Cracow \\ Institute of Geography \\ Department of Entrepreneurship and Spatial Management \\ ul. Podchorążych 2, 30-084 Kraków, Poland \\ mplaziak@up.krakow.pl
}


